This document is confidential and is proprietary to the American Chemical Society and its authors. Do not copy or disclose without written permission. If you have received this item in error, notify the sender and delete all copies.

\title{
Peroxide Activation Regulated by Hydrogen Bonds within Artificial Cu Proteins
}

\begin{tabular}{|r|l|}
\hline Journal: & Journal of the American Chemical Society \\
\hline Manuscript ID & ja-2017-104524.R1 \\
\hline Danuscript Type: & Communication \\
\hline Complete List of Authors: & $\begin{array}{l}\text { Mann, Samuel; University of California-Irvine, Chemistry } \\
\text { Heinisch, Tillmann; University Basel, Chemistry } \\
\text { Ward, Thomas; University of Basel, Department of Chemistry } \\
\text { Borovik, Andrew; University of California-Irvine, Chemistry }\end{array}$ \\
\hline
\end{tabular}

\section{SCHOLARONE \\ Manuscripts}


The utilization of dioxygen in biology is critical for most forms of life and is often achieved using metalloproteins. A subset of these enzymes contain a monomeric $\mathrm{Cu}$ center as exemplified by the copper-dependent lytic polysaccharide monooxygenases (LPMOs). These fungal and bacterial enzymes assist in the extracellular degradation of polysaccharides such as cellulose into oligosaccharides via initial oxidation, and are linked in biomass conversion to biofuels. The mechanistic details are still uncertain with questions persisting on the identity of the key dioxygen adducts that lead to oxidation. Possible candidates include $\mathrm{Cu}^{\mathrm{II}}$-hydroperoxido species (Figure 1A), whose structures are often only inferred as they are inherently unstable at room temperature. ${ }^{1}$

A persistent challenge in studying these systems is finding suitable model systems whose structure can simulate protein active sites. Because protein function is regulated largely by the structural properties of the protein matrix, it has been difficult to design model systems that closely mimic the local protein architecture that regulates $\mathrm{O}_{2}$ activation. ${ }^{2-6}$ Although site architectures are diverse in monooxygenases, they share the common characteristic

that non-covalent interactions, especially hydrogen bonds (H-bonds), control metal-mediated $\mathrm{O}_{2}$ activation. ${ }^{7-9}$ For instance, dioxygen affinities to hemoglobins are correlated to $\mathrm{H}$-bonding networks involving the $\mathrm{Fe}-\mathrm{O}_{2}$ unit (Figure $1 \mathrm{~B}$ ) where at least one $\mathrm{H}$-bond to the proximal $\mathrm{O}$ atom $\left(\mathrm{O}_{\mathrm{p}}\right)$ is needed to form stable species. ${ }^{10,11}$ In contrast, $\mathrm{O}-\mathrm{O}$ bond cleavage in cytochrome $\mathrm{P} 450$ s and peroxidases require specific $\mathrm{H}$-bonds involving only the distal O-atom $\left(\mathrm{O}_{\mathrm{d}}\right)$ of the $\mathrm{Fe}-\mathrm{OOH}$ unit (Figure $\left.1 \mathrm{C}\right){ }^{12-14}$ Related proposals have been advanced for $\mathrm{Cu}-\mathrm{OOH}$ species in LPMOs, in which $\mathrm{H}$-bonds to the $\mathrm{O}_{\mathrm{d}}$-atom of the hydroperoxido ligand leads to productive $\mathrm{C}-\mathrm{H}$ bond cleavage of substrates $^{15,16}$ (Figure 1A).

To investigate the relationship between $\mathrm{H}$-bonding networks and regulation of Cu-hydroperoxido complexes, we present herein artificial copper proteins that were designed to stabilize a $\mathrm{Cu}^{\mathrm{II}}-\mathrm{OOH}$ complex in aqueous solution and in crystallo using biotin-streptavidin (Sav) technology. This approach relies on the strong binding of biotinylated metal complexes to the Sav host, leading to the precise localization of the synthetic metal cofactors within a protein environment. ${ }^{17}$ Structure-function relationships between the local environment and the stability of the $\mathrm{Cu}-\mathrm{OOH}$ complex were evaluated using a series of
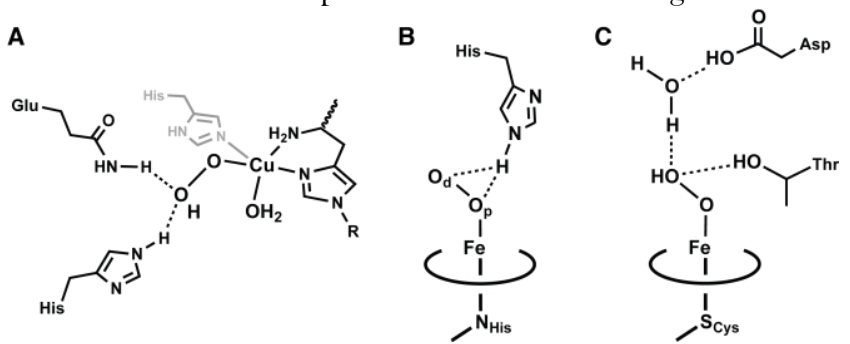

Figure 1. Representations of the H-bonds involved in the proposed $\mathrm{Cu}^{\mathrm{II}}-\mathrm{OOH}$ intermediate formed during catalytic turnover for $\mathrm{Cu}$-LPMOs (A), ${ }^{1}$ in stabilizing the $\mathrm{Fe}-\mathrm{O}_{2}$ species in the active sites of hemoglobins (B, PDB 1GZX), ${ }^{11}$ and in activating the $\mathrm{Fe}-\mathrm{OOH}$ species in $\mathrm{P} 450 \mathrm{~s}$ (C). ${ }^{14}$ The dashed lines indicate $\mathrm{H}$-bonds, the circular lines represent protoporphyrin IX, and $\mathrm{O}_{\mathrm{p}}$ and $\mathrm{O}_{\mathrm{d}}$ denote the proximal and distal positions.

\section{ACS Paragon Plus Environment}


Sav variants in which individual H-bonds were systematically deleted.

Within this context, we initially examined the biotinylated $\mathrm{Cu}^{\text {II }}$ complex, $\left[\mathrm{Cu}{ }^{\text {II }} \text { (biot-et-dpea) }\left(\mathrm{H}_{2} \mathrm{O}\right)_{2}\right]^{2+}$ (Figure 2A) and found that it can react with $\mathrm{H}_{2} \mathrm{O}_{2}$ in buffer $\mathrm{A}$ (50 $\mathrm{mM}$ MES at $\mathrm{pH}$ 6) at room temperature to form a new complex with spectroscopic properties that are similar to those of known $\mathrm{Cu}^{\mathrm{II}}-\mathrm{OOH}$ species $\left(\lambda_{\max }=375 \mathrm{~nm}, \varepsilon_{\mathrm{M}}=\right.$ 1800 (Figures 2C \& S1, Table S1). ${ }^{15,18-25}$ However, the complex is unstable and decays with a half-life of $6 \mathrm{~min}$ (Figure S1). The decay of $\left[\mathrm{Cu}^{\mathrm{II}}\right.$ (biot-etdpea) $\left.\left(\mathrm{H}_{2} \mathrm{O}\right)(\mathrm{OOH})\right]^{2+}$ is similar to that observed in other synthetic systems and illustrates the inherent instability of $\mathrm{Cu}^{\mathrm{II}}-\mathrm{OOH}$ under ambient conditions. ${ }^{21}$

Confinement of the $\mathrm{Cu}$ complex within Sav WT produced a stable $\mathrm{Cu}^{\text {II }}-\mathrm{OOH}$ species. These studies utilized $\left[\mathrm{Cu}^{\mathrm{II}} \text { (biot-et-dpea) }\left(\mathrm{H}_{2} \mathrm{O}\right)_{2}\right]^{2+} \subset \mathrm{Sav}$ WT (1) which is an $\mathrm{ArM}$ that contains a five-coordinate $\mathrm{Cu}^{\text {II }}$ center with two coordinated water molecules (Figure 2B). Its molecular structure (PDB 5WBC) revealed an H-bonding network involving the aqua ligand containing $\mathrm{O} 3$, the structural water molecule $(\mathrm{O} 1)$, the side chain $\mathrm{O}$-atom of residue S112, and the backbone carbonyl O-atom from A86. ${ }^{26}$ The placement of $\mathrm{O} 1$ is noteworthy as it is present in many structures of Sav WT that we have studied and is positioned to $\mathrm{H}$-bond to ligands coordinated to $\mathrm{CCu}^{\mathrm{II}}$ (biotet-dpea) $]^{2+}$. Treating 1 with excess $\mathrm{H}_{2} \mathrm{O}_{2}$ in buffer A (Figure $2 \mathrm{C} \& 3$ ) produced changes in the absorbance spectrum that are, again, indicative of formation of a $\mathrm{Cu}^{\mathrm{II}}$ $\mathrm{OOH}$ species, that is $\left[\mathrm{Cu}^{\mathrm{II}}(\text { biot-et-dpea })\left(\mathrm{H}_{2} \mathrm{O}\right)(\mathrm{OOH})\right]^{+}$ $\subset$ Sav WT (2). Unlike in our control experiment with $\left[\mathrm{Cu}^{\mathrm{II}} \text { (biot-et-dpea) }\left(\mathrm{H}_{2} \mathrm{O}\right)_{2}\right]^{2+}$ without Sav, the band at $\lambda_{\max }=$ $375 \mathrm{~nm}$ for 2 persisted for over a day at room temperature, indicating that confinement within Sav increased the stability of the $\mathrm{Cu}^{\mathrm{II}}-\mathrm{OOH}$ adduct in solution (Figure S2). ${ }^{27}$ In addition, the electron paramagnetic resonance spectrum of 2 showed small changes in the $\mathrm{g}$ - and Avalues that are consistent with the binding of a hydroperoxido ligand to the copper center (Figure S2, Table S1). ${ }^{20}$

The formation of 2 was also achieved in crystallo by incubating single crystals of 1 in a cryoprotectant solution containing $1.0 \mathrm{mM} \mathrm{H}_{2} \mathrm{O}_{2}$ at $\mathrm{pH}=6$ for 10 minutes (see SI). The $1.62 \AA$ resolution structure of 2 collected at short exposure times (Table S3) showed that each subunit contained a 5-coordinate $\mathrm{Cu}$ complex with a distorted trigo- nal bipyramidal structure (Figures $4 \&$ S3): three of the coordination sites are occupied by the $\mathrm{N}$-atoms from the dpea ligand and the fourth site is occupied by an aqua ligand $(\mathrm{O} 2){ }^{28}$ The remaining coordination site contains a ligand that was modeled to be a 2-atom fragment that is assigned to the end-on hydroperoxido ligand with $\mathrm{Cu}-\mathrm{O} 3$ and O3-O4 bond lengths of 1.94(2) and 1.52(2) $\AA$ and a $\mathrm{Cu}-\mathrm{O} 3-\mathrm{O} 4$ bond angle of $138(2)^{\circ}$ (Figures $4 \mathrm{~A} \& \mathrm{~B}, \mathrm{~S} 3$, Table S2). Comparing the structures of 1 and 2 , the $\mathrm{Cu}(\mathrm{dpea})$ portion of the complexes occupies the same position, but replacing the aqua ligand $(\mathrm{O} 3)$ in 1 with the peroxido ligand in 2 results in a shortening of the $\mathrm{Cu}-\mathrm{O} 3$ bond distance by nearly $0.6 \AA$ (Figure S3 \& Table S2). Note that the metrical parameters for the $\mathrm{Cu}$ complex in 2 are similar to those reported for the only synthetic monomeric $\mathrm{Cu}-\mathrm{OOH}$ complex: $\mathrm{Cu}-\mathrm{N}$ bond distances are statistically the same, whereas the $\mathrm{Cu}-\mathrm{O} 3$ and $\mathrm{O} 3-\mathrm{O} 4$ bond lengths are slightly longer in $2 .^{18}$ The $\mathrm{O}-\mathrm{O}$ bond length in 2 is also the same as that found in the structures of LPMO whose $\mathrm{Cu}^{\mathrm{II}}$ active sites are proposed to also contain a peroxide molecule. ${ }^{29,30}$ In addition, the O3-O4 and $\mathrm{Cu}-\mathrm{O} 3$ bond distances are the same as those found for a proposed mononuclear $\mathrm{Cu}-\mathrm{OOH}$ species in ascorbate oxidase trapped in crystallo. ${ }^{31}$

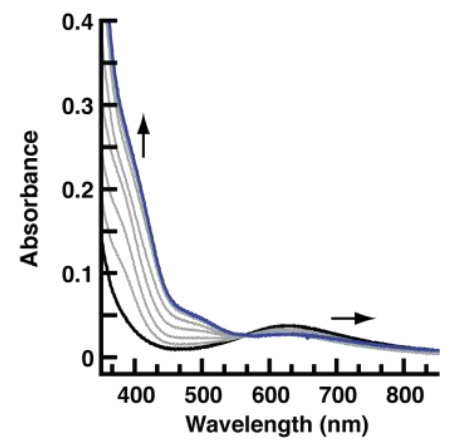

Figure 3. Absorbance spectral changes for the conversion of 1 (black) to 2 (blue) at room temperature in buffer A.

An important structural outcome was the H-bonding network that surrounds the $\mathrm{Cu}-\mathrm{OOH}$ unit that we suggest contributes to the stability of this species. The $\mathrm{Cu}$ complex is anchored within Sav in such a way that the hydroperoxido ligand is canted toward residue N49 which forms an $\mathrm{H}$-bond with the $\mathrm{O}_{\mathrm{d}}$-atom $(\mathrm{O} 4)$. A second $\mathrm{H}$ bond is formed between $\mathrm{O} 1$ and the $\mathrm{O}_{\mathrm{p}}$-atom (O3). This type of $\mathrm{H}$-bonding network around a hydroperoxido ligand that involves both $\mathrm{O}$-atoms is, to our knowledge, unknown in other $\mathrm{Cu}$ systems and highlights the natural
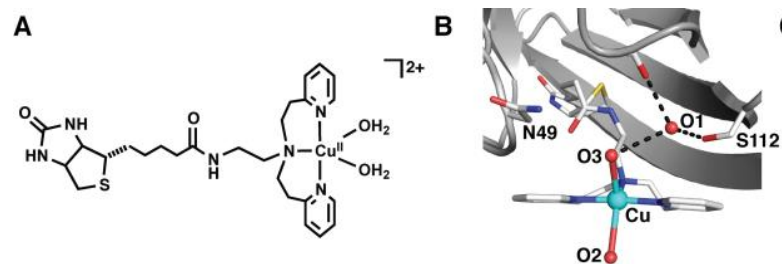

C

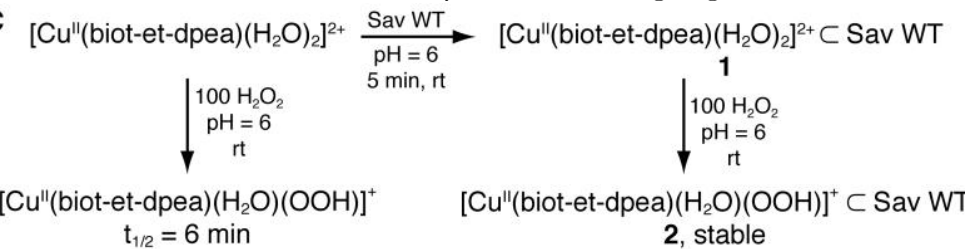

Figure 2. Representation of biotinylated $\mathrm{Cu}$ complex $\left[\mathrm{Cu}^{\mathrm{II}}\left(\text { biot-et-dpea) }\left(\mathrm{H}_{2} \mathrm{O}\right)_{2}\right]^{2+}(\mathrm{A})\right.$, the molecular structure of 1 (B, PDB $5 \mathrm{~K} 49),{ }^{26}$ and the reaction conditions to form 2 (C). The dashed lines indicate H-bonds. 

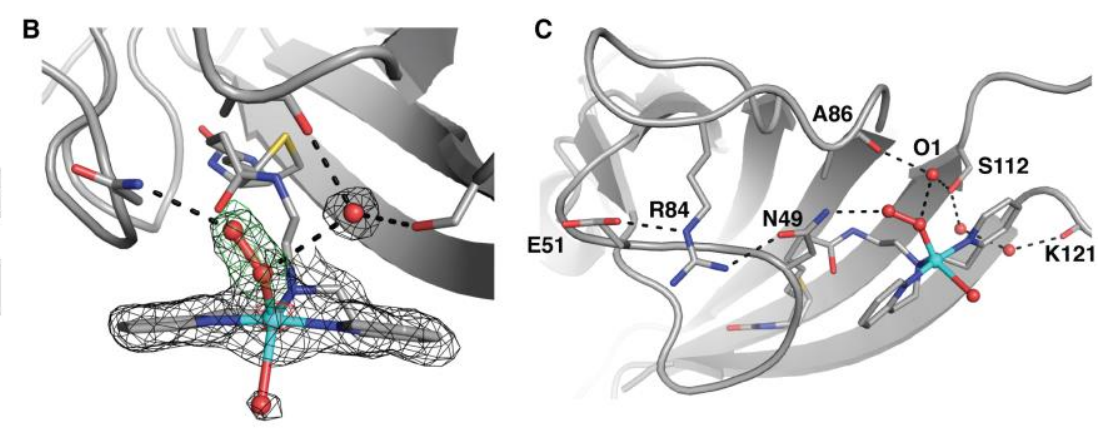

Figure 4. The molecular structure of 2 (A \& B, PDB: 6ANX) and the extended H-bonding network surrounding the $\mathrm{Cu}-\mathrm{OOH}$ complex (C). The $2 F_{0}-F_{c}$ electron density map (grey, contoured at $\left.1 \sigma\right), F_{0}-F_{c}$ omit map (green, contoured at $3 \sigma$ ) and anomalous difference density (red, contoured at $10 \sigma$ ) are highlighted in B. Copper ions are colored in cyan, O-atoms are colored in red, $\mathrm{N}$ atoms are colored in blue, and $\mathrm{C}$-atoms are colored in gray. $\mathrm{H}$-bonds are indicated as dashed lines. Selected metrical data ( $\mathrm{A}$ or

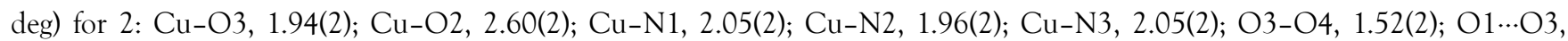
3.18(2); O4 $\cdots \mathrm{N} 4,3.04(2)$; $\mathrm{Cu}-\mathrm{O} 3-\mathrm{O} 4,138(2)^{\circ}$; N1-Cu-O2, 109(2) ${ }^{\circ}$. Note that some photo-reduction is possible during the collection as we have found diminished electron density for $\mathrm{O} 2$ at higher dose of X-ray. ${ }^{28}$ See SI and reference 28 for details.

cleft provided by Sav for this metallocofactor (Figures 4A \& S3). In addition, the side chain of N49 and the water molecule containing $\mathrm{O} 1$ participate in extended $\mathrm{H}$ bonding networks that assist in positioning the $\mathrm{H}$-bonds to the $\mathrm{Cu}-\mathrm{OOH}$ complex (Figure $4 \mathrm{C}$ ). The position of the N49 side chain is fixed via a H-bonding network that includes the carboxylic acid sidechain of E51 and the guanidinium sidechain of R84. This H-bonding network suggests that the HN4 of the N49 amide side chain donates an $\mathrm{H}$-bond to the $\mathrm{Cu}-\mathrm{OOH}$ unit. The side chain in S112 has an additional H-bonding contact with another water molecule, which is part of a larger network that includes the carbonyl O-atom of K121. This orientation of H-bonds is consistent with the hydroxyl group of S112 serving as an $\mathrm{H}$-bond donor to $\mathrm{O} 1$.

The premise that the stability of the $\mathrm{Cu}^{\mathrm{II}}-\mathrm{OOH}$ complexes in $\mathbf{2}$ is correlated to the $\mathrm{H}$-bonding network within the local environment was evaluated using two different variants of Sav. Mutations to alanine were engineered at either N49 or S112 that would alter the local environment to possibly modulate the stability of the $\mathrm{Cu}-\mathrm{OOH}$ unit. In one variant, $\left[\mathrm{Cu}^{\mathrm{II}}(\text { biot-et-dpea })\left(\mathrm{H}_{2} \mathrm{O}\right)_{2}\right]^{2+} \subset \mathrm{Sav}$ $\mathrm{S}_{112} \mathrm{~A}$ (3) was prepared in order to remove the structural water molecule containing $\mathrm{O} 1$ because it can no longer form an $\mathrm{H}$-bond with the engineered alanine residue at position $\mathrm{S}_{112} \mathrm{~A}$. The $1.4 \AA$ structure of 3 showed that the occupancy of the water molecule containing $\mathrm{O} 1$ is reduced substantially by approximately $50 \%$ and no $\mathrm{H}$ bonds are formed with the confined $\mathrm{Cu}$ complex (Figure S4). This structural analysis showed that the $\mathrm{Cu}$ complex is no longer locked into a single position as in $\mathbf{1}$ and $\mathbf{2 \text { , }}$ but is disordered over two positions that we attribute to the lack of a H-bond to fix the position of the complex within Sav (Figure S4). Treating a solution of 3 with $\mathrm{H}_{2} \mathrm{O}_{2}$ at room temperature in buffer $\mathrm{A}$ produced $\left[\mathrm{Cu}^{\mathrm{II}}\right.$ (biot-etdpea) $\left.\left(\mathrm{H}_{2} \mathrm{O}\right)(\mathrm{OOH})\right]^{+} \subset \mathrm{Sav} \mathrm{S}_{112} \mathrm{~A}$ (4) that had an initial absorbance spectrum nearly identical to that of 2 . However, 4 was not stable and decayed with a half-life of 20 min (Figure S5) that prevented formation in crystallo. The structure of the other variant [Cu ${ }^{\text {II }}$ (biot-et-dpea) $\left.\left(\mathrm{H}_{2} \mathrm{O}\right)\right]^{2+} \subset \mathrm{Sav} \mathrm{N}_{49} \mathrm{~A}(5,1.6 \AA$ A , Fig. S6) revealed a similar $\mathrm{Cu}^{\mathrm{II}}$ complex to that in 1 . Moreover, the key water molecule $(\mathrm{O} 1)$ is present in the same position and forms a $\mathrm{H}$ bond to the coordinate aqua ligand $\mathrm{O} 3$. Variant $\mathbf{5}$ was reacted with $\mathrm{H}_{2} \mathrm{O}_{2}$ in buffer $\mathrm{A}$ to produce $\left[\mathrm{Cu}^{\mathrm{II}}\right.$ (biot-etdpea) $\left.\left(\mathrm{H}_{2} \mathrm{O}\right)(\mathrm{OOH})\right]^{+} \subset \mathrm{Sav} \mathrm{N}_{49} \mathrm{~A}(6)$ that had similar solution stability as 2 (Figure S5). Despite the stability of 6 attempts to prepare it in crystallo were unsuccessful: XRD analyses of all crystals showed a $\mathrm{Cu}^{\mathrm{II}}$-aqua complex that was similar to that observed in $\mathbf{5}$.

The effects of the intramolecular H-bonds were further explored with reactivity studies involving external substrates. No reactivity was observed when 2 was treated with substrates having $\mathrm{C}-\mathrm{H}$ bonds in solution at room temperature (buffer A). For example, treating 2 with 4chlorobenzylamine showed no change in the absorbance spectrum and no detectable products after $1 \mathrm{~h}$. A similar lack of reactivity was observed for 6 , the ArM that has $\mathrm{N}_{49} \mathrm{~A}$ mutation. Gratifyingly, we observed oxidation products with 4: in a typical reaction, ArM 4 was treated with 4-chlorobenzylamine at room temperature and the absorbance band at $\lambda_{\max }=375 \mathrm{~nm}$ disappeared within 10 min (Figure S7). Analysis of the organic products revealed that N-(4-chorobenzyl)-1-(4-chlorophenyl)meth-animine (7) was produced (65\% yield relative to $\mathrm{Cu}$, Figure S8). For-

Scheme 1.

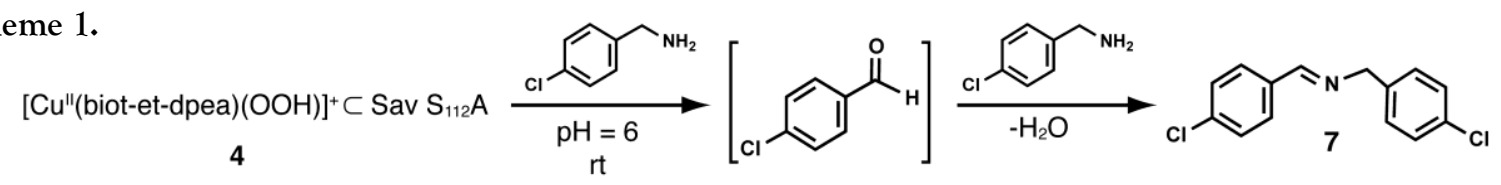


mation of this product is consistent with an initial oxidation of the amine and hydrolysis to afford the oxidized species 4-chlorobenzaldehyde that further reacts with the remaining amine to produce the Schiff base 7 (Scheme 1). In control experiments, $\left[\mathrm{Cu}^{\mathrm{II}} \text { (biot-et-dpea) }\left(\mathrm{H}_{2} \mathrm{O}\right)(\mathrm{OOH})\right]^{+}$ was treated with 4-chlorobenzyl-amine under the same conditions used with 4: analysis of the reaction mixture by ESI-MS revealed a small molecular ion peak for 7, but attempts to quantify the amount produced by NMR spectroscopy were below the detection limits.

Using biotin-Sav technology we demonstrate that ArMs can be designed and prepared that stabilize $\mathrm{Cu}^{\mathrm{II}}-\mathrm{OOH}$ species by precisely engineering the local $\mathrm{H}$-bonding environment. The fusion of synthetic and protein chemistries offers the promise for capturing unattainable reactive species under ambient conditions in aqueous solutionsakin to what occurs in biology. Correlating the changes in reactivity of the $\mathrm{Cu}^{\mathrm{II}}-\mathrm{OOH}$ complex with modulation of the H-bonds highlights their critical role in regulating the function of metal-hydroperoxido intermediates (Figure 5). A single $\mathrm{H}$-bond to the proximal O-atom of the hydroperoxido ligand was essential to form a stable $\mathrm{Cu}-\mathrm{OOH}$ within the protein host. Varying the H-bonding network to include only the distal O-atom produced a reactive variant that oxidized a substrate. For LPMOs, our experimental findings suggest a dioxygen binding site in which $\mathrm{H}$-bonds participate in the activation of a $\mathrm{Cu}^{\mathrm{II}}-\mathrm{OOH}$ intermediate. Moreover, our correlations support the

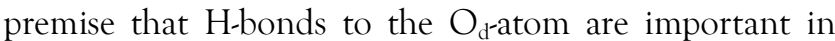
the activation of a hydroperoxido ligand within the active site of proteins. ${ }^{1,15,16}$ These findings highlight that the positioning of a single $\mathrm{H}$-bond to a metal-hydroperoxido complex can be the difference between functional or dysfunctional metalloproteins.

\section{ASSOCIATED CONTENT}

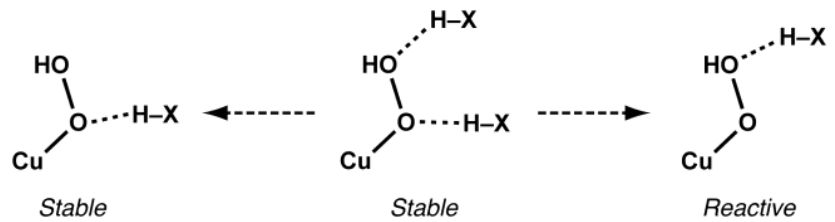

Figure 5. Proposed effects of $\mathrm{H}$-bonds on $\mathrm{Cu}-\mathrm{OOH}$ species.

Supporting Information. The Supporting Information is available free of charge via the Internet at http://pubs.acs.org.

Methods, addition experimental parameters, and supporting figures (PDF).

\section{AUTHOR INFORMATION}

\section{Corresponding Author}

*aborovik@uci.edu
Notes

No competing financial interests have been declared.

\section{ACKNOWLEDGMENT}

The authors thank the NIH (GM50781-21S1 to ASB/TRW, and GM120349 to ASB) for financial support and T. Poulos, P.H. Walton, H. Li, and J. Klehr for helpful discussions.

\section{REFERENCES}

(1) Span, E. A.; Suess, D. L. M.; Deller, M. C.; Britt, R. D.; Marletta, M. A. ACS Chem. Biol. 2017, 12, 1095.

(2) Song, W. J.; Tezcan, F. A. Science 2014, 346, 1525.

(3) Berggren, G.; Adamska, A.; Lambertz, C.; Simmons, T. R.; Esselborn, J.; Atta, M.; Gambarelli, S.; Mouesca, J. M.; Reijerse, E.; Lubitz, W.; Happe, T.; Artero, V.; Fontecave, M. Nature 2013, 498, 66.

(4) Cavazza, C.; Bochot, C.; Rousselot-Pailley, P.; Carpentier, P.; Cherrier, M. V; Martin, L.; Marchi-Delapierre, C.; Fontecilla-Camps, J. C.; Ménage, S. Nat. Chem. 2010, 2, 1069.

(5) Reig, A. J.; Pires, M. M.; Snyder, R. A.; Wu, Y.; Jo, H.; Kulp, D. W.; Butch, S. E.; Calhoun, J. R.; Szyperski, T.; Szyperski, T. G.; Solomon, E. I.; DeGrado, W. F. Nat. Chem. 2012, 4, 900.

(6) Petrik, I. D.; Liu, J.; Lu, Y. Curr. Opin. Chem. Biol. 2014, 19, 67.

(7) Miller, A.-F. Acc. Chem. Res. 2008, 41, 501.

(8) Cook, S. A.; Hill, E. A.; Borovik, A. S. Biochemistry 2015, 54, 4167.

(9) Liu, J.; Chakraborty, S.; Hosseinzadeh, P.; Yu, Y.; Tian, S.; Petrik, I.; Bhagi, A.; Lu, Y. Chem. Rev. 2014, 114, 4366.

(10) Shaanan, B. Nature 1982, 296, 683.

(11) Paoli, M.; Liddington, R.; Tame, J.; Wilkinson, A.; Dodson, G. J. Mol. Biol. 1996, 256, 775 .

(12) Poulos, T. L. Chem. Rev. 2014, 114, 3919.

(13) Gerber, N. C.; Sligar, S. G. J. Am. Chem. Soc. 1992, 114, 8742.

(14) Martinis, S. A.; Atkins, W. M.; Stayton, P. S.; Sligar, S. G. J. Am. Chem. Soc. 1989, 111, 9252.

(15) Yamaguchi, S.; Nagatomo, S.; Kitagawa, T.; Funahashi, Y.; Ozawa, T.; Jitsukawa, K.; Masuda, H. Inorg. Chem. 2003, 42, 6968.

(16) Tian, G.; Berry, J. A.; Klinman, J. P. Biochemistry 1994, 33, 226.

(17) Heinisch, T.; Ward, T. R. Acc. Chem. Res. 2016, 49, 1711.

(18) Wada, A.; Harata, M.; Hasegawa, K.; Jitsukawa, K.; Masuda, H.; Mukai, M.; Kitagawa, T.; Einaga, H. Angew. Chem. Int. Ed. 1998, 3, 798.

(19) Chen, P.; Fujisawa, K.; Solomon, E. I. J. Am. Chem. Soc. 2000, 122, 10177.

(20) Maiti, D.; Sarjeant, A. A. N.; Karlin, K. D. J. Am. Chem. Soc. 2007, 129, 6720 .

(21) Zhu, Q.; Lian, Y.; Thyagarajan, S.; Rokita, S. E.; Karlin, K. D.; Blough, N. V. J. Am. Chem. Soc. 2008, 130, 6304.

(22) Kunishita, A.; Scanlon, J. D.; Ishimaru, H.; Honda, K.; Ogura, T.; Suzuki, M.; Cramer, C. J.; Itoh, S. Inorg. Chem. 2008, 47, 8222.

(23) Maiti, D.; Narducci Sarjeant, A. A.; Karlin, K. D. Inorg. Chem. 2008, $47,8736$.

(24) Kim, S.; Saracini, C.; Siegler, M. A.; Drichko, N.; Karlin, K. D. Inorg. Chem. 2012, 51, 12603 .

(25) Itoh, S. Acc. Chem. Res. 2015, 48, 2066.

(26) Mann, S. I.; Heinisch, T.; Weitz, A. C.; Hendrich, M. P.; Ward, T. R.; Borovik, A. S. J. Am. Chem. Soc. 2016, 138, 9073.

(27) Attempts to measure the resonance Raman spectra of all ArMs and free $\mathrm{Cu}$ complexes were unsuccessful due to strong background fluorescence that obscured the signals.

(28) We solved the structures of several crystals of 2 collected a different Xray exposure times to evaluate the effects of possible photoreduction on the crystals. For the shorter times $(0.35 \mathrm{~s} / 0.5 \mathrm{deg})$ we observed the structure shown in Figure 4 with a 5 -coordinate $\mathrm{Cu}^{\mathrm{II}}-\mathrm{OOH}$ species. For the longer times $(1 \mathrm{~s} / 0.5 \mathrm{deg})$ the $\mathrm{Cu}^{\mathrm{II}}-\mathrm{OOH}$ complex is 4-coordinate with aqua ligand containing $\mathrm{O} 2$ not observed (PDB 5WBA, Figure S2) that is attributed to partial photoreduction. However, all other metrical parameters are the same within experimental error (Table S2) and the structures support the assignment of a $\mathrm{Cu}^{\mathrm{II}}-\mathrm{OOH}$.

(29) Li, X.; Beeson, W. T.; Phillips, C. M.; Marletta, M. A.; Cate, J. H. D. Structure 2012, 20, 1051. 
(30) O’Dell, W. B.; Agarwal, P. K.; Meilleur, F. Angew. Chem. Int. Ed.. 2017, 56,767 .

1

2

(31) Messerschmidt, A.; Luecke, H.; Huber, R. J. Mol. Biol. 1993, 230, 997.
4

5

6

7

8

9

10

11

12

13

14

15

16

17

18

19

20

21

22

23

24

25

26

27

28

29

30

31

32

33

34

35

36

37

38

39

40

41

42

43

44

45

46

47

48

49

50

51

52

53

54

55

56

57

58

59

60 
For Table of Contents Only

2

-

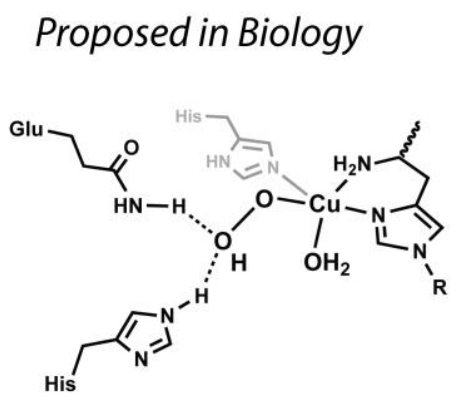

Engineered in a Protein

4

5

6

7

8

9

10

11

12

13

14

15

16

17

18

19

20

21

22

23

24

25

26

27

28

29

30

31

32

33

34

35

36

37

38

39

40

41

42

43

44

45

46

47

48

49

50

51

52

53

54

55

56

57

58

59

60

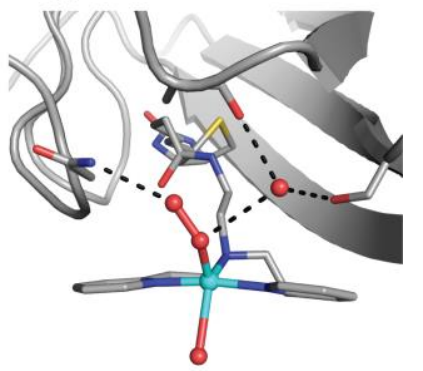




1
2
3
4
5
6
7
8
9
10
11
12
13
14
15
16
17
18
19
20
21
22
23
24
25
26
27
28
29
30
31
32
33
34
35
36
37
38
39
40
41
42
43
40
45
49
50
51
52
53
55
50

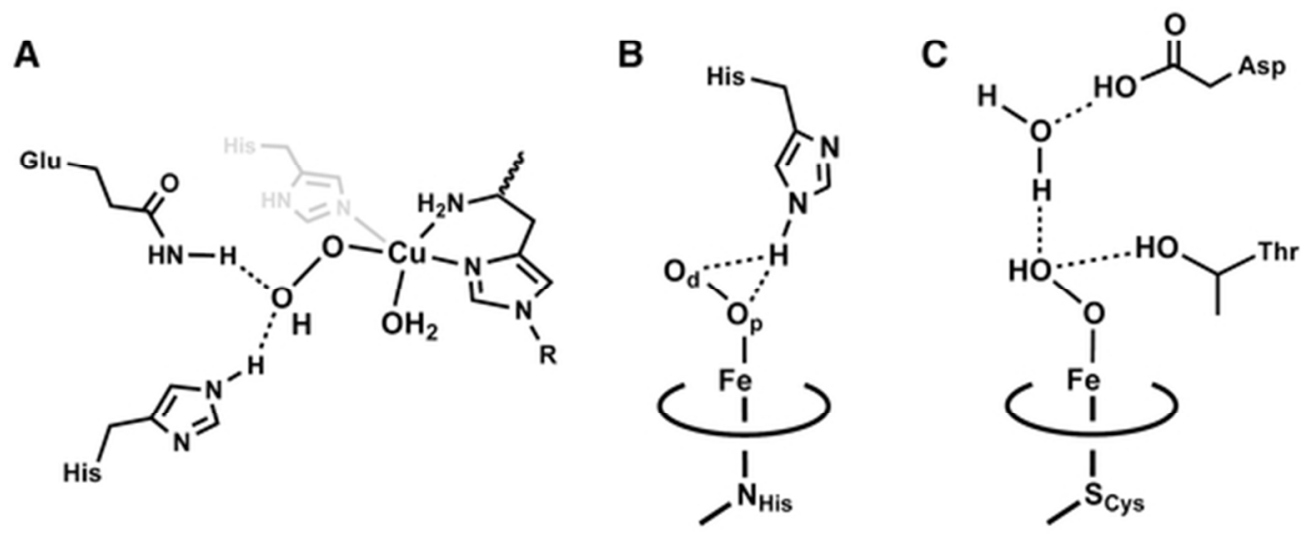

Figure 1

$51 \times 24 \mathrm{~mm}(300 \times 300$ DPI $)$ 


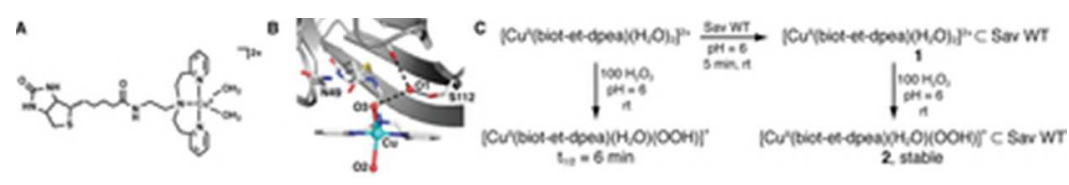

Figure 2

$34 \times 5 \mathrm{~mm}(300 \times 300$ DPI) 


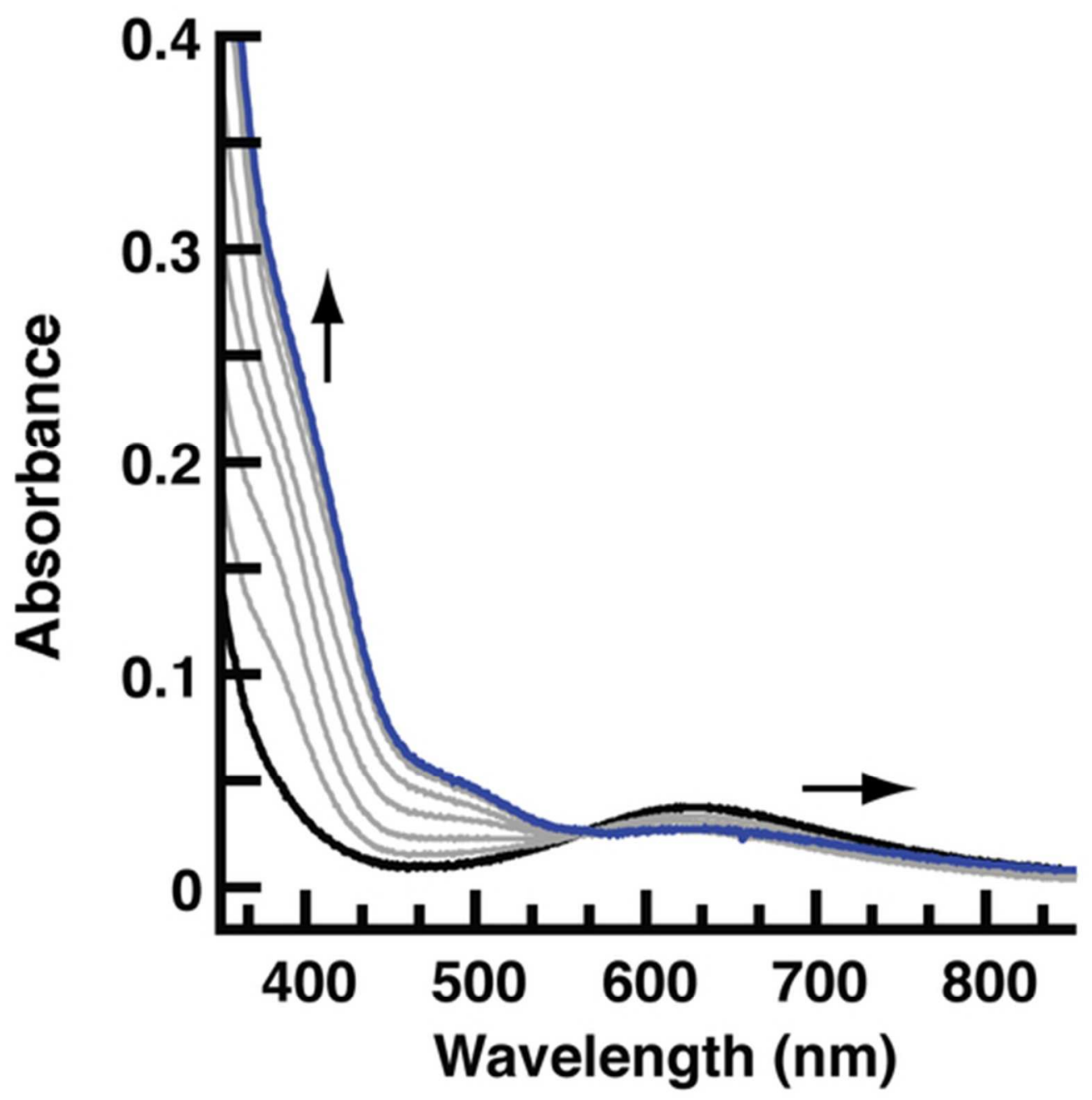

Figure 3

$44 \times 45 \mathrm{~mm}(300 \times 300 \mathrm{DPI})$ 

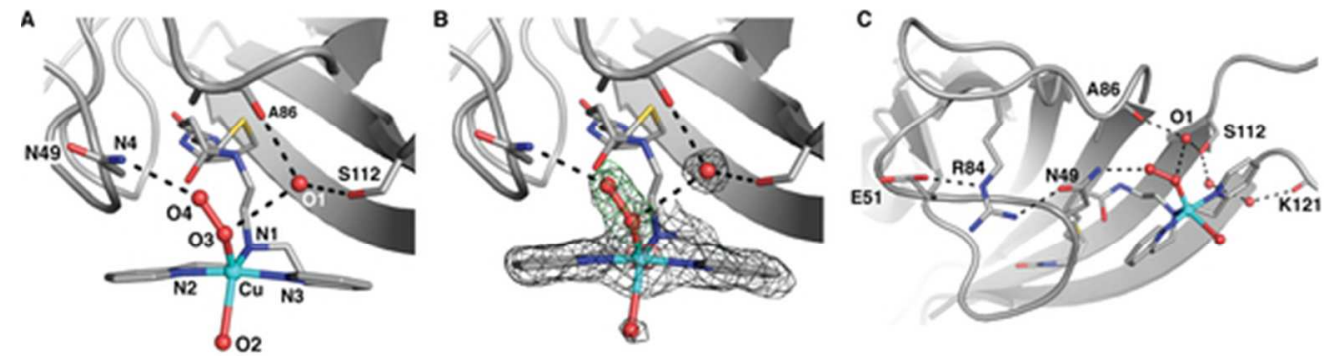

Figure 4

$47 \times 12 \mathrm{~mm}(300 \times 300$ DPI $)$ 


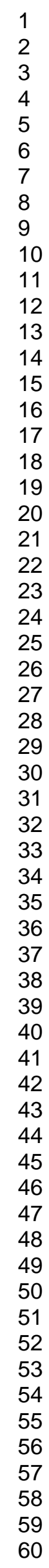

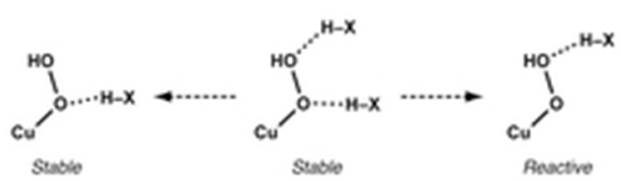

Figure 5

$20 \times 5 \mathrm{~mm}(300 \times 300 \mathrm{DPI})$ 


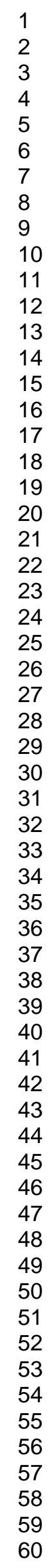

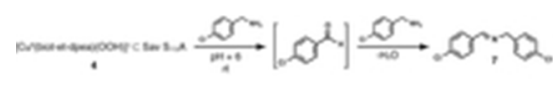

Scheme 1

$17 \times 2 \mathrm{~mm}(300 \times 300 \mathrm{DPI})$ 

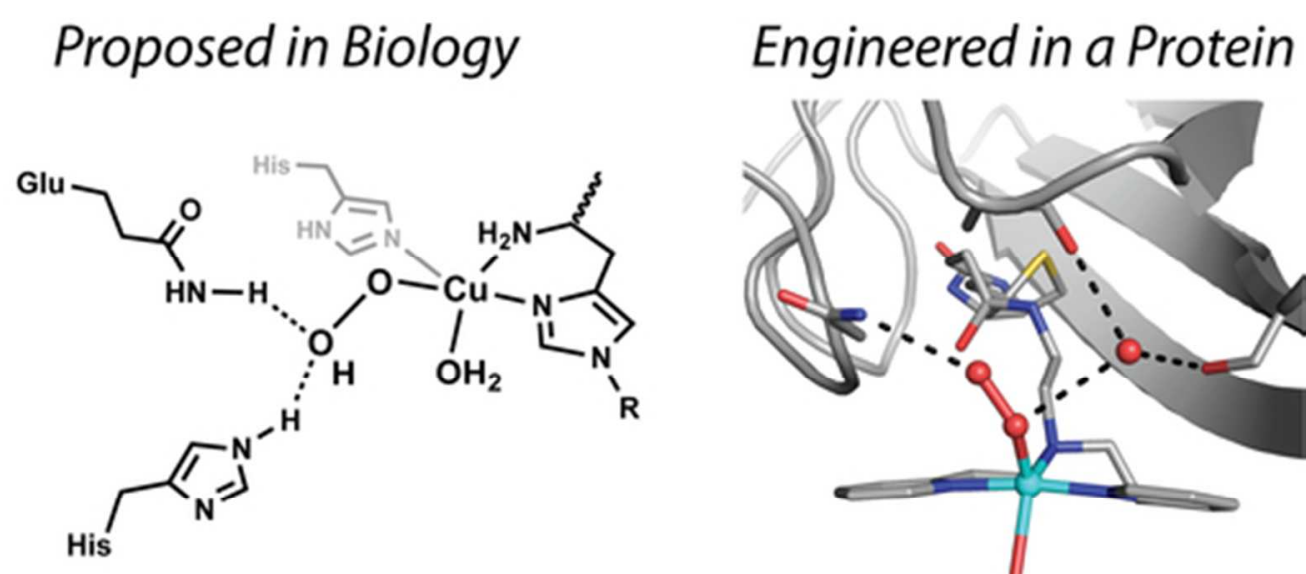

1
2
3
4
5
6
7
8
9

10

11

12

13

14

15

16

17

18

19

20

21

22

23

24

25

26

27

28

29

30

31

32

33

34

35

36

37

38

39

40

41

42

43

44

45

46

47

48

49

50

51

52

53

54

55

56

57

58

59

60

TOC Figure

42×19mm (300 x 300 DPI) 